\title{
Inotuzumab ozogamicin in clinical development for acute lymphoblastic leukemia and non-Hodgkin lymphoma
}

\author{
Amandeep Aujla', Ravijot Aujla ${ }^{2}$ and Delong Liu, ${ }^{1,3^{*}}$ (D)
}

\begin{abstract}
B cell acute lymphoblastic leukemia (ALL) and non-Hodgkin lymphoma (NHL) frequently express CD19, CD20 and CD22 on the cell surfaces. Immunotherapeutic agents including antibodies and chimeric antigen receptor T cells are widely studied in clinical trials. Several antibody-drug conjugates (ADC) have been approved for clinical use (gemtuzumab ozogamicin in acute myeloid leukemia and brentuximab vedotin in Hodgkin lymphoma as well as CD30+ anaplastic large cell lymphoma). Inotuzumab ozogamicin (INO), a CD22 antibody conjugated with calicheamicin is one of the newest ADCs. INO has been approved for treatment of relapsed/refractory B cell precursor ALL. Multiple ongoing trials are evaluating its role in the relapsed /refractory B cell NHL. This review summarized recent development in INO applications for ALL and NHL.
\end{abstract}

Keywords: Acute lymphoblastic leukemia, CD22, Inotuzumab ozogamicin, Non-Hodgkin lymphoma, Antibody-drug conjugate, ADC

\section{Introduction}

The prognosis of adults with relapsed / refractory (R/R) acute lymphoblastic leukemia (ALL) and non-Hodgkin lymphoma (NHL) is still very poor [1-5]. With the increasing use of next-generation sequencing (NGS) and molecular biomarkers, early diagnosis and targeted therapy become possible [6-10]. It appears that NGS-based minimal residue disease (MRD) monitoring may better predict MRD relapse and lead to earlier intervention [11]. B cell ALL and NHL frequently express CD19, CD20 and $\mathrm{CD} 22$ on the cell surfaces. Monoclonal antibodies (MoAb) against CD20 have been widely used for the treatment of multiple lymphoid malignancies [12-14]. Immunotherapy with bispecific antibodies such as blinatumomab against CD19 is being studied in multiple types of B cell malignancies [15-23]. Immune checkpoint inhibitors have also been approved for treatment of Hodgkin lymphoma [24]. Chimeric antigen receptor (CAR) $\mathrm{T}$ cells are also being widely studied in clinical trials [25-31]. CD19 is the most

\footnotetext{
* Correspondence: DELONG_LIU@NYMC.EDU

'Department of Medicine, New York Medical College and Westchester Medical Center, Valhalla, NY 10595, USA

${ }^{3}$ Department of Oncology, The First affiliated hospital of Zhengzhou

University, Zhengzhou, China

Full list of author information is available at the end of the article
}

commonly targeted surface marker in CAR T trials [3237]. CD20, CD22, and CD30 are also targeted antigens of CAR T cells in ALL and lymphoma trials [26]. Tisagenlecleucel has been approved for R/R B ALL and diffuse large B cell lymphoma (DLBCL) [36, 38-42]. In addition, axicabtagene ciloleucel has been approved for R/R DLBCL $[43,44]$.

In addition to the above immunotherapeutic agents, conjugation of cytotoxic agents with monoclonal antibodies is an evolving field with the development of multiple targeted cytotoxic agents called antibody-drug conjugates (ADC) [45]. These are being used and studied with targets across different malignancies (e.g. trastuzumab emtansine in breast cancer, gemtuzumab ozogamicin in acute myeloid leukemia and brentuximab vedotin in Hodgkin lymphoma as well as CD30+ anaplastic large cell lymphoma) [46-52]. Inotuzumab ozogamicin (INO), a CD22 MoAb conjugated with calicheamicin is one of the newest ADCs in clinical application [53, 54]. INO has been approved for treatment of R/R B cell precursor ALL [55-63]. Multiple ongoing trials are evaluating its role in the R/R B cell NHL. This review summarized recent development in INO applications for B cell ALL and NHL.

(C) The Author(s). 2019 Open Access This article is distributed under the terms of the Creative Commons Attribution 4.0 International License (http://creativecommons.org/licenses/by/4.0/), which permits unrestricted use, distribution, and reproduction in any medium, provided you give appropriate credit to the original author(s) and the source, provide a link to the Creative Commons license, and indicate if changes were made. The Creative Commons Public Domain Dedication waiver (http://creativecommons.org/publicdomain/zero/1.0/) applies to the data made available in this article, unless otherwise stated. 


\section{CD22 expression and function}

$\mathrm{CD} 22$ is an inhibitory component of the B-cell receptor (BCR) complex expressed exclusively in pre- $\mathrm{B}$, immature and mature $B$ cells but is lost upon differentiation to plasma cells [64-66]. It mediates negative impact on BCR signaling pathway by dephosphorylating the associated cascade components via protein tyrosine phosphatases [67-69] (Fig. 1).

\section{CD22 positivity in lymphoid malignancies}

CD22 expression increases progressively along the pathway of B cell maturation. Raponi et al. reported CD22 expression among different subtypes of ALL as $83 \%$ of Pro-B, $96.4 \%$ of common B cell, $91.9 \%$ of Pre-B and $100 \%$ of the mature B cell ALL [70]. In mature B cell lymphoma, its expression has been reported as $95 \%$ in chronic lymphocytic leukemia, $89 \%$ in diffuse large B-cell lymphoma, $98 \%$ in follicular lymphoma, $96 \%$ in lymphoplasmacytic lymphoma and $100 \%$ in hairy cell, mantle cell, marginal zone, splenic marginal zone lymphomas and monoclonal B-lymphocytosis [71]. Hence CD22 can serve as a good target for therapy of B cell malignancies.

\section{Inotuzumab ozogamicin: CD22 antibody-drug conjugate}

Structure and function

Inotuzumab is a humanized IgG4 monoclonal antibody that binds CD22. It is conjugated via an acid labile linker to the cytotoxic chemotherapy, calicheamicin ( $\mathrm{N}$-acet$y \mathrm{l}-\gamma$-calicheamicin dimethyl hydrazide). Calicheamicin is a potent cytotoxic antibiotic that binds DNA in the minor groove and causes double-strand DNA breaks leading to cell death [72]. Binding of drug to CD22 receptor leads to its endocytosis and cytotoxic chemotherapy is released in acidic lysosomal environment with degradation of the linker. CD22 receptor is then recycled back to the surface and may play a role in augmented efficacy $[73,74]$.

\section{Preclinical studies}

CD22 monoclonal antibody (MoAb) with or without conjugation to calicheamicin has similar affinity to CD22 receptors on human B-lymphoma cells [73]. In vitro studies showed enhancement of cytotoxic potency of calicheamicin by 1.5 to 39 -fold when conjugated to CD22 MoAb against CD22 ${ }^{+}$B-lymphoma cell lines. INO

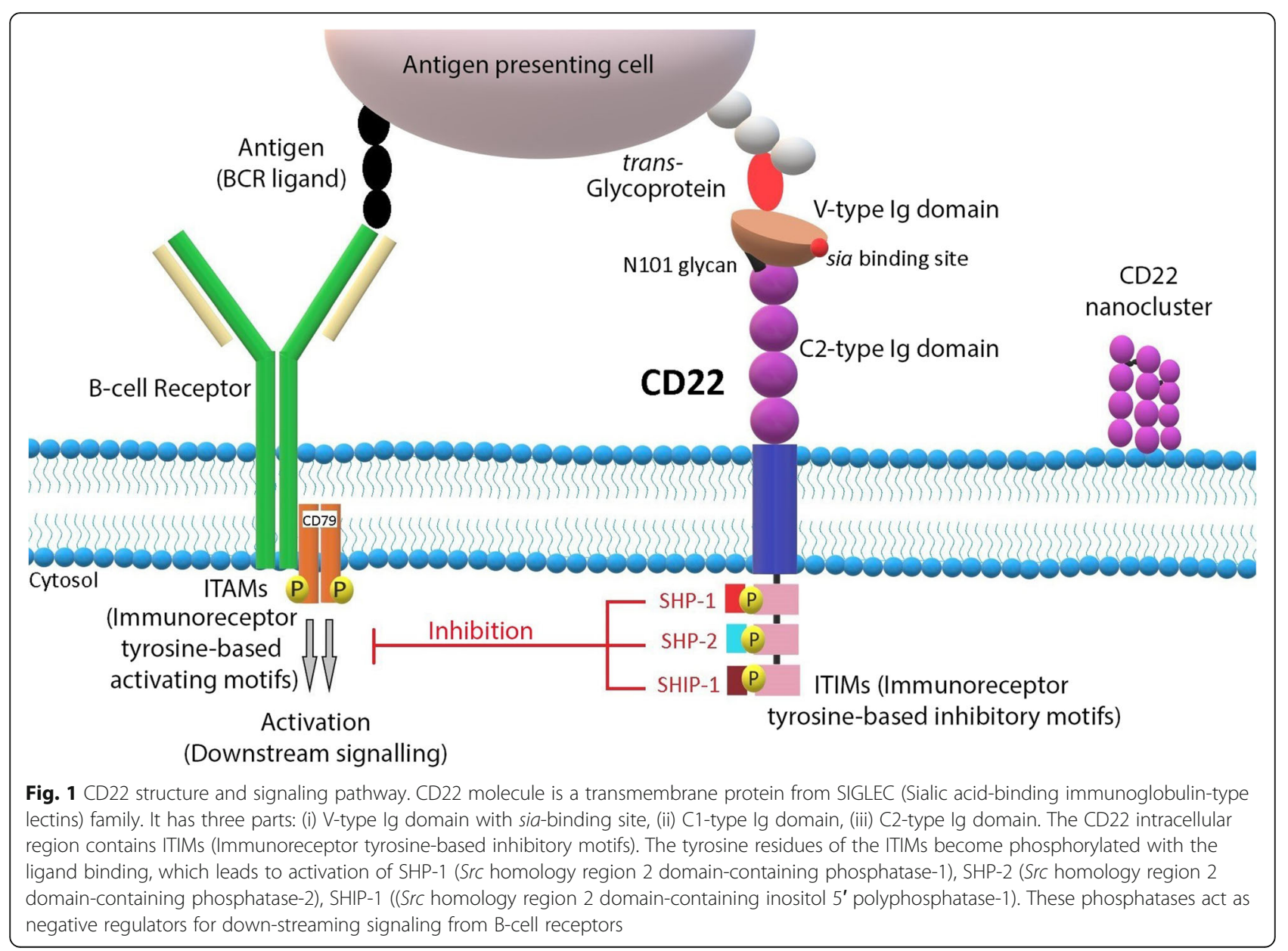


(CMC-544) was noted to inhibit the growth of CD22 ${ }^{+}$ human B-cell lymphomas grafted subcutaneously into the mice in a dose dependent manner. Half-life of CMC-544 is $35 \mathrm{~h}$ and was noted to be similar in both tumor bearing and non-tumor bearing mice. However AUC (area under curve) of serum levels in tumor bearing mice was noted to be $37 \%$ lower, suggesting absorption by targeted tumor tissue [73]. Similar preclinical studies in mice with ALL cells and subcutaneous xenografts also showed that INO not only inhibited the growth of ALL xenografts but also prevented engraftment of ALL cells and development of disseminated disease in SCID (severe combined immune deficiency) mice $[75,76]$. These results were also replicated in pediatric B-ALL cells with additional findings that efficacy (inducing apoptosis) is not dependent on CD22 expression and receptor saturation, in contrast to gemtuzumab ozogamicin [77]. High expression of CD22 was reported to accelerate the response in comparison to low CD22 expression cell lines.

\section{Clinical trials of inotuzumab ozogamicin in ALL}

Phase 1 dose finding study for Inotuzumab ozogamicin (INO) in CD22-positive R/R ALL was done with 1.2, 1.6, or $1.8 \mathrm{mg} / \mathrm{m} 2$ doses per cycle on days 1,8 , and 15 over a 28-daycycle [78]. The recommended phase 2 dose (RP2D) was determined to be $1.8 \mathrm{mg} / \mathrm{m} 2$ (Table 1).

The safety and efficacy of INO were further assessed in phase 2 expansion cohort. INO was given as $0.8 \mathrm{mg} /$ $\mathrm{m} 2$ on day $1 ; 0.5 \mathrm{mg} / \mathrm{m} 2$ on days 8 and 15 ; The dosage was lowered to $1.6 \mathrm{mg} / \mathrm{m} 2$ per cycle after complete remission (CR) or $\mathrm{CR}$ with incomplete marrow recovery (CRi). CR/CRi was achieved in 69\% (CR 29\%) with RP2D and MRD negativity was reported in $75 \%$ of this population (CR/CRi). Median progression free survival (PFS) in all treated population was 3.9 months and median overall survival (OS) of 7.4 months. Twenty-four out of $72(33 \%)$ patients in total proceeded to allogeneic stem cell transplant (AlloSCT) and most of the patients were given fludarabine and/or total body irradiation (TBI) based conditioning regimen except one patient who received dual alkylator conditioning (cyclophosphamide, thiotepa, and fludarabine). Among these, 12 deaths occurred ( 2 died due to relapse/progressive disease; 7 died $\leq 100$ days due to sepsis, graft-versus-host disease, venoocclusive disease and respiratory failure). Four patients developed venoocclusive disease (VOD), none of whom had received pre-study AlloSCT (Two patients experienced VOD during therapy or follow-up without AlloSCT and two developed VOD after AlloSCT) [78].

INO has been approved by FDA for treatment of adults with $\mathrm{R} / \mathrm{R}$ B-cell precursor ALL based on results of INO-VATE trial [63]. This phase 3 trial compared INO given as $0.8 \mathrm{mg} / \mathrm{m} 2$ on day (D) 1 followed by $0.5 \mathrm{mg} / \mathrm{m} 2$ on D8 and D15 (total $1.8 \mathrm{mg} / \mathrm{m} 2$ every 4 weeks) against standard chemotherapy in $\mathrm{Ph}$-positive or $\mathrm{Ph}$-negative refractory or relapsed B-ALL. Chemotherapy regimens included FLAG (Fludarabine, cytarabine and Granulocyte stimulating factor), cytarabine with mitoxantrone or cytarabine alone. This phase 3 study demonstrated that single agent INO led to a significantly higher CR rate than that in the chemotherapy group $(80.7 \%$ vs. $29.4 \% ; p<0.001)$, and a longer CR duration (4.6 vs. 3.1 months; $p=0.03$ ).

Veno-occlusive disease (VOD) with liver function abnormality and weight gain was a major adverse event. Therefore, careful planning for INO therapy prior to AlloSCT is important to minimize VOD complications. It is generally advised that length of INO therapy should be limited. Longer spacing from end of INO therapy to AlloSCT is also being studied, such as adding blinatumomab as consolidation prior to AlloSCT $[79,80]$.

INO has also been studied in a phase 2 trial in combination with chemotherapy for $R / R$ Philadelphia chromosome-negative ALL [55]. It was combined with mini-Hyper-CVD regimen (miniHCVD) (cyclophosphamide $150 \mathrm{mg} / \mathrm{m} 2$ every $12 \mathrm{~h}$ on days $1-3$, dexamethasone $20 \mathrm{mg} /$ day on days $1-4$ and $11-14$, and vincristine $2 \mathrm{mg}$ flat dose on days 1 and 8, alternating with methotrexate $250 \mathrm{mg} / \mathrm{m} 2$ on day 1 and cytarabine $0.5 \mathrm{~g} / \mathrm{m} 2$ every $12 \mathrm{~h}$ on days 2 and $3[55,56]$. INO was administered on day 3 of cycles 1 through 4 . INO was given as $1.3 \mathrm{mg} / \mathrm{m} 2$ for cycle 1 followed by $1 \mathrm{mg} / \mathrm{m} 2$ for cycles 2 to 4 (the details of the schedules and doses were summarized in the tables of the reference [81]). Investigators started ursodiol $300 \mathrm{mg}$ three times daily as VOD prophylaxis later as protocol amendment. Maintenance therapy was given as per POMP regimen (for details of the regimen, see references $[55,59,81])$. ORR was $78 \%$ (59\% CR) with MRD negative rates of $52 \%$ (at time of morphological response) and $82 \%$ (at 3 months). OS rate at 1 year was $46 \%$ (mOS of 11 months). mOS was noted to be higher in patients treated as first salvage regimen (mOS approaching 17 months) compared to those receiving as second salvage regimen. VOD was observed in $6 / 26(23 \%)$ patients who underwent subsequent AlloSCT and 3/33 (9\%) in those who did not receive AlloSCT. All VOD cases had received clofarabine based conditioning regimens with or without busulfan. For patients who are candidates for AlloSCT, treatment with INO should be limited to 2 cycles of induction or the fewest number of cycles required to achieve a CR/CRi (if CR/CRi not achieved after 2 cycles) $[55,79,80]$.

\section{Clinical trials of inotuzumab ozogamicin in NHL}

Preclinical Studies confirmed the potency and dose-dependent cytotoxicity of INO on CD22 positive B-lymphoma cell lines and anti-tumor efficacy in mouse 
Table 1 Clinical trials of inotuzumab ozogamicin (INO)

\begin{tabular}{|c|c|c|c|c|c|c|c|}
\hline Reference & Phase & Disease & Intervention INO + & ORR (CR) & mPFS & $\mathrm{mOS}$ & Significant toxicities \\
\hline [55] & 2 & $\begin{array}{l}\text { R/R Ph-Negative CD22 } \\
\text { positive ALL }\end{array}$ & $\begin{array}{l}\text { Mini-Hyper-CVD with } \\
\text { INO and Rituximab }\end{array}$ & $\begin{array}{l}\text { ORR was 78\% (59\% } \\
\text { CR) MRD negative } \\
\text { rates of 52\% (at time } \\
\text { of morphological } \\
\text { response) and } 82 \% \text { (at } \\
3 \text { months). }\end{array}$ & $\begin{array}{l}\text { Median } \\
\text { RFS of } 8 \\
\text { months. }\end{array}$ & 11 months & $\begin{array}{l}\text { VOD }(15 \%) \text {; prolonged } \\
\text { thrombocytopenia } \\
(81 \%) ; 95 \% \text { suffered } \\
\text { hepatotoxicity (20\% with } \\
\text { grade } 3 \text { or higher) }\end{array}$ \\
\hline [63] & 3 & Refractory or Relapsed ALL & $\begin{array}{l}0.8 \mathrm{mg} / \mathrm{m} 2(\mathrm{D} 1), 0.5 \\
\mathrm{mg} / \mathrm{m} 2 \text { (D8), } 0.5 \mathrm{mg} / \\
\mathrm{m} 2 \text { (D15) } \\
\text { Versus } \\
\text { Standard therapy }\end{array}$ & $\begin{array}{l}\text { CR + CRi 80.7\% (CR } \\
35.8 \%)\end{array}$ & 5 months & 7.7 months & $\begin{array}{l}\text { Grade } 3 \text { or more } \\
\text { thrombocytopenia, } \\
\text { hepatotoxicity and VOD } \\
(11 \%)\end{array}$ \\
\hline [78] & $1 / 2$ & R/R ALL & $1.8 \mathrm{mg} / \mathrm{m} 2$ weekly & 69\% CR/CRi (29\% CR) & & & $\begin{array}{l}\text { cytopenias and liver } \\
\text { toxicity }\end{array}$ \\
\hline [84] & 1 & R/R FL (100\%) & $\begin{array}{l}\text { Single agent } \\
1.3 \mathrm{mg} / \mathrm{m} 2 \mathrm{q} 28 \mathrm{~d} \text { with } \\
\text { dose escalation up to } \\
\text { MTD } 1.8 \mathrm{mg} / \mathrm{m} 2 \mathrm{q} 28 \mathrm{~d}\end{array}$ & $\begin{array}{l}\text { CR: } 54 \% \\
\text { ORR: } 85 \%\end{array}$ & - & - & $\begin{array}{l}\text { No DLTs. MTD of } 1.8 \\
\mathrm{mg} / \mathrm{m} 2 \text { confirmed in } \\
\text { Japanese population. }\end{array}$ \\
\hline [85] & $1 / 2$ & $\begin{array}{l}\text { CD20 and CD22 positive B- } \\
\text { NHL. Relapsed follicular } \\
\text { lymphoma (35\%), Relapsed } \\
\text { diffuse large B-cell lymph } \\
\text { oma (39\%), or refractory } \\
\text { aggressive NHL (25\%) }\end{array}$ & $\begin{array}{l}\text { Dose escalation (0.8, } 1.3 \\
\text { and } 1.8 \mathrm{mg} / \mathrm{m} 2) \text { study } \\
\text { in combination with } \\
\text { Rituximab } 375 \mathrm{mg} / \mathrm{m} 2 \\
\text { MTD of determined to } \\
\text { be } 1.8 \mathrm{mg} / \mathrm{m} 2 \text {. }\end{array}$ & $\begin{array}{l}\text { FL: } 87 \%(62 \%) \\
\text { DLBCL: } 74 \%(50 \%) \\
\text { Refractory: } 20 \%\end{array}$ & $\begin{array}{l}\text { FL: NR (2 } \\
\text { year PFS } \\
\text { rate of } \\
68 \%) \\
\text { DLBCL: } \\
17.1 \\
\text { months } \\
\text { Refractory: } \\
1.9 \\
\text { months. }\end{array}$ & $\begin{array}{l}\text { FL: } 2 \text { year } \\
\text { OS rate } \\
90 \% \\
\text { DLBCL: } 3 \\
\text { year OS } \\
\text { rate 69\% } \\
\text { Refractory: } \\
8.8 \text { months }\end{array}$ & $\begin{array}{l}\text { Grade } 3 \text { to } 4 \\
\text { thrombocytopenia (31\%) } \\
\text { and neutropenia (22\%). } \\
\text { SAEs of Pneumonia (4\%), } \\
\text { Sepsis (3\%) and liver } \\
\text { dysfunction (4\%). No } \\
\text { VOD. }\end{array}$ \\
\hline [86] & 1 & $\begin{array}{l}\text { B-NHL (CD20 and CD22- } \\
\text { positive, B-cell NHL which } \\
\text { has progressed after } 1 \text { or } 2 \\
\text { prior therapies) }\end{array}$ & $\begin{array}{l}1.8 \mathrm{mg} / \mathrm{m} 2 \text {, IV on day } 2 \\
\text { of each } 28 \text { day cycle; up } \\
\text { to } 8 \text { cycles }+\mathrm{R} 375 \mathrm{mg} / \\
\mathrm{m} 2 \text {, IV on day } 1 \text { of each } \\
28 \text { day cycle; up to } 8 \\
\text { cycles }\end{array}$ & $80 \%(60 \%)$ & NR & NR & $\begin{array}{l}\text { 90\% SAEs, with } \\
\text { thrombocytopenia, } \\
\text { neutropenia, elevated } \\
\text { liver enzymes and } \\
\text { hypophosphatemia }\end{array}$ \\
\hline [87] & 1 & $\begin{array}{l}\mathrm{CD} 22 \text { positive } \mathrm{NHL} \text { with at } \\
\text { least } 1 \text { prior treatment }\end{array}$ & INO $(0.8 \mathrm{mg} / \mathrm{m} 2)+\mathrm{RCVP}$ & $84 \%(24 \%)$ & $\begin{array}{l}14.4 \\
\text { months }\end{array}$ & $\begin{array}{l}24.5 \\
\text { months }\end{array}$ & $\begin{array}{l}1 \text { death due to } \\
\text { neutropenic pneumonia } \\
\text { in INO-CVP arm. (13/48) } \\
27 \% \text { discontinued ther- } \\
\text { apy in INO-CVP arm due } \\
\text { to adverse effects }\end{array}$ \\
\hline \multirow[t]{3}{*}{ [88] } & \multirow[t]{3}{*}{$1 / 2$} & \multirow{3}{*}{$\begin{array}{l}\text { CD22 positive NHL with at } \\
\text { least } 1 \text { prior treatment; } \\
\text { DLBCL (38\%) FL }(25 \%) \text { MCL } \\
\text { (24\%) Refractory }(42 \%)\end{array}$} & \multirow{3}{*}{$\begin{array}{l}\text { INO }(0.8 \mathrm{mg} / \mathrm{m} 2)+\mathrm{R}- \\
\text { GDP }\end{array}$} & Phase 1: 53\% (20\%); & \multirow{3}{*}{$\begin{array}{l}6 \mathrm{~m}: 58 \% \\
12 \mathrm{~m}: 37 \% \\
24 \mathrm{~m}: 24 \%\end{array}$} & \multirow{3}{*}{$\begin{array}{l}6 \mathrm{~m}: 81 \% \\
12 \mathrm{~m}: 61 \% \\
24 \mathrm{~m}: 55 \%\end{array}$} & \multirow{3}{*}{$\begin{array}{l}\text { Grade } 3 \text { or more } \\
\text { thrombocytopenia } \\
\text { (75\%); neutropenia } \\
\text { (62\%). One patient with } \\
\text { grade } 3 \text { VOD. }\end{array}$} \\
\hline & & & & $\begin{array}{l}\text { Phase } 2 \text { dose (RP2D): } \\
50 \%(14 \%)\end{array}$ & & & \\
\hline & & & & Refractory: 35\% & & & \\
\hline
\end{tabular}

Abbreviations: $R / R$ refractory /relapsed, $C V D$ cyclophosphamide vincristine dexamethasone, $m$ month, ORR overall response rate, $C R$ complete remission, $P F S$ progression free survival, OS overall survival, RFS relapse free survival, VOD veno-occlusive disease, NHL non-Hodgkin lymphoma, NR not reached, MRD minimal residual disease, MTD maximal tolerated dose, SAE serious adverse event, $D L B C L$ diffuse large $B$ cell lymphoma, $F L$ follicular lymphoma, $M C L$ mantle cell lymphoma, $R P 2 D$ recommended phase 2 dose, GDP gemcitabine dexamethasone cisplatin

models with B-cell lymphomas [72, 73]. When combined with rituximab, additive anti-tumor activity with superior efficacy was achieved in vitro on human B-lymphoma cell lines [82].

Phase 1 studies of INO monotherapy determined maximum tolerated dose (MTD) of $1.8 \mathrm{mg} / \mathrm{m} 2$ every 4 weeks in humans with grade 3 or higher thrombocytopenia and neutropenia as the dose-limiting toxicities (DLT). VOD was reported in patients post autologous stem-cell transplant setting and those with prior history of VOD like syndrome $[83,84]$. Phase $1 / 2$ study of INO in combination with rituximab $(375 \mathrm{mg} / \mathrm{m} 2)$ every 4 weeks determined MTD of $1.8 \mathrm{mg} / \mathrm{m} 2$ every 4 weeks and showed ORR of 87,74 and $20 \%$ in relapsed follicular lymphoma (FL), relapsed DLBCL and refractory B-NHL respectively. $68 \%$ of relapsed FL remained progression free at 2 years with median PFS of 17.1 months in relapsed DLBCL and 1.9 months in refractory disease [85]. Thrombocytopenia (56\%; 31\% grade 3 or higher) and neutropenia (34\%; $22 \%$ grade 3 or higher) were the most common adverse events requiring dose modification. Serious adverse events included pneumonia (4\%), sepsis (3\%) and liver dysfunction (4\%). 
Table 2 Ongoing trials of inotuzumab ozogamicin (INO)

\begin{tabular}{|c|c|c|c|c|}
\hline Reference & Phase & Disease & Intervention & Recruitment \\
\hline NCT03441061 & 2 & B-ALL with positive MRD & INO & Recruiting \\
\hline NCT03677596 & 4 & $\mathrm{R} / \mathrm{R}$ B-ALL & $\begin{array}{l}\text { Investigating lower dose level }(1.2 \mathrm{mg} / \mathrm{m} 2 / \mathrm{cycle}) \text { for those } \\
\text { with higher risk for liver toxicity or VOD. }\end{array}$ & $\begin{array}{l}\text { Not yet } \\
\text { recruiting }\end{array}$ \\
\hline NCT03460522 & 2 & Precursor B-cell ALL in 56-74 years old & INO induction followed by conventional chemotherapy & Recruiting \\
\hline NCT02311998 & $1 / 2$ & Ph + B-ALL and CML-blast phase & Bosutinib plus INO & Recruiting \\
\hline NCT01925131 & 1 & $\begin{array}{l}\text { Acute leukemia of ambiguous lineage, Recurrent Ph } \\
+ \text { B-ALL, Recurrent Burkitt Lymphoma }\end{array}$ & INO plus CVP (cyclophosphamide, Vincristine, Prednisone) & Recruiting \\
\hline NCT03739814 & 2 & Ph negative B-ALL & INO followed by Blinatumomab & Recruiting \\
\hline NCT03851081 & $1 / 2$ & $r / r$ B-ALL & INO plus Vincristine (liposomal) & $\begin{array}{l}\text { Not yet } \\
\text { Recruiting }\end{array}$ \\
\hline NCT01664910 & $1 / 2$ & Conditioning regimen for $\mathrm{HSCT}$ & INO + plus Rituximab, Bendamustine and Fludarabine & Recruiting \\
\hline NCT03249870 & 2 & Ph negative B-ALL in 55 years or older & INO plus CVP induction & Recruiting \\
\hline NCT03610438 & 2 & ALL with positive MRD prior to HSCT & INO & $\begin{array}{l}\text { Not yet } \\
\text { recruiting }\end{array}$ \\
\hline NCT03856216 & 2 & Allogeneic SCT & Pre and Post HSCT INO & $\begin{array}{l}\text { Not yet } \\
\text { recruiting }\end{array}$ \\
\hline NCT01371630 & $1 / 2$ & Untreated ALL in 60 years and older & INO plus combination chemotherapy & $\begin{array}{l}\text { Not yet } \\
\text { recruiting }\end{array}$ \\
\hline NCT03150693 & 3 & Newly diagnosed B-ALL in 18-39years old & INO plus chemotherapy & Recruiting \\
\hline NCT03094611 & 2 & R/R ALL & Lower dose INO & Recruiting \\
\hline NCT03488225 & 2 & ALL & INO plus HyperCVAD & Recruiting \\
\hline NCT01679119 & 2 & DLBCL & $\begin{array}{l}\text { INO plus R-CVP versus } \\
\text { Gem-R-CVP }\end{array}$ & Recruiting \\
\hline NCT02981628 & 2 & B-ALL in $1-21$ years old & INO & Recruiting \\
\hline NCT03628053 & 3 & ALL & Tisagenlecleucel versus Blinatumomab or Inotuzumab & $\begin{array}{l}\text { Not yet } \\
\text { recruiting }\end{array}$ \\
\hline
\end{tabular}

Abbreviations: $R / R$ refractory /relapsed, $C V A D$ cyclophosphamide vincristine Adriamycin dexamethasone, NHL non-Hodgkin lymphoma, $D L B C L$ diffuse large B cell lymphoma, ALL acute lymphoblastic leukemia, Gem gemcitabine, $R$ rituximab, CVP cyclophosphamide vincristine prednisone, VOD veno-occlusive disease

Similar phase 1 study with the combination of rituximab $(375 \mathrm{mg} / \mathrm{m} 2)$ and standard dose INO $(1.8 \mathrm{mg} / \mathrm{m} 2)$ every 4 weeks was studied in the Japanese population [86]. Nine out of 10 patients experienced grade 3 or higher adverse events including thrombocytopenia, neutropenia, elevated liver enzymes and hypophosphatemia; 5 out of 10 patients discontinued treatment because of these adverse events. Overall respone rate (ORR) was reported at $80 \%$ (CR $60 \%$ ).

INO in reduced dose of $0.8 \mathrm{mg} / \mathrm{m} 2$ once every 3 weeks has also been studied in combination with rituximabbased chemo-immunotherapy regimens. Phase 1 study of INO in combination with R-CVP (Rituximab, Cyclophosphamide, Vincristine and Prednisone) determined $0.8 \mathrm{mg} /$ $\mathrm{m} 2$ as MTD with DLT of reversible grade 4 neutropenia [87]. ORR of $84 \%$ (CR 24\%) was reported in MTD cohort along with median PFS of 14.4 months and median OS of 24.5 months (aggressive NHL; NR in indolent NHL).

Another phase 1 study of INO $(0.8 \mathrm{mg} / \mathrm{m} 2$ every 3 weeks) in combination with R-GDP (Rituximab, Gemcitabine, Dexamethasone, Cisplatin) reported ORR of 53\% (CR 20\%) in refractory/relapsed B-cell NHL with major toxicities of grade 3 or higher thrombocytopenia (75\%), neutropenia (62\%) and one case of VOD [88] (Table 1).

\section{Veno-occlusive disease associated with inotuzumab ozogamicin}

VOD as seen with gemtuzumab ozogamicin has been reported with the use of INO in the setting of autologous or allogeneic transplant [55-57, 59, 63, 73, 85]. A retrospective study of 26 patients with refractory ALL received INO followed by AlloSCT. Conditioning regimens consisted of cyclophosphamide, clofarabine, fludarabine, melphalan, thiotepa and total body irradiation [89]. Five patients suffered fatal hepatic VOD at a median of 23 days after SCT. In particular, patients who received conditioning with double-alkylating agents (e.g., high-dose busulfan and cyclophosphamide) may be at especially higher risk of VOD [90]. Splitting INO dosage appears to be useful to minimize VOD $[55,56]$. Incorporation of blinatumomab as consolidation in the miniHCVD -INO-blinatumomab regimen increases the time between INO and AlloSCT $[55,56,59,81]$. This may further decrease the VOD risk. 


\section{Conclusion}

Single agent inotuzumab ozogamicin has shown higher response rates and longer duration of remission in direct comparison against intensive chemotherapies for $R / R B$ cell ALL. Incorporation of INO into miniHCVD regimen appears to be effective with less toxicity. Although results from NHL trials have not been as encouraging, further studies are still ongoing (Table 2).

\section{Abbreviations}

CAR: Chimeric antigen receptor; DLBCL: Diffuse large B cell lymphoma; INO: Inotuzumab ozogamicin

\section{Acknowledgements}

$\mathrm{DL}$ is a professor of medicine in the Department of Medicine, New York Medical.

College and Westchester Medical Center, Valhalla, NY, USA.

\section{Funding}

The study is partly supported by the First Affiliated Hospital of Zhengzhou University, Zhengzhou, China.

\section{Availability of data and materials}

The material supporting the conclusion of this review has been included within the article.

\section{Authors' contributions}

$\mathrm{DL}$ and AA designed the study and drafted the manuscript. All authors participated in the revision of the manuscript. All authors read and approved the final manuscript.

\section{Ethics approval and consent to participate}

This is not applicable for this review.

\section{Consent for publication}

This is not applicable for this review.

\section{Competing interests}

The authors declare that they have no competing interests.

\section{Publisher's Note}

Springer Nature remains neutral with regard to jurisdictional claims in published maps and institutional affiliations.

\section{Author details}

'Department of Medicine, New York Medical College and Westchester Medical Center, Valhalla, NY 10595, USA. ${ }^{2}$ Punjab Institute of Medical Sciences, Jalandhar, Punjab 144006, India. ${ }^{3}$ Department of Oncology, The First affiliated hospital of Zhengzhou University, Zhengzhou, China.

\section{Received: 18 February 2019 Accepted: 27 March 2019}

Published online: 11 April 2019

\section{References}

1. Abou Dalle I, Jabbour E, Short NJ, Ravandi F. Treatment of Philadelphia chromosome-positive acute lymphoblastic leukemia. Curr Treat Options in Oncol. 2019;20(1):4.

2. Frey NV, Luger SM. How I treat adults with relapsed or refractory Philadelphia chromosome-negative acute lymphoblastic leukemia. Blood. 2015;126(5):589-96.

3. Hunger SP, Mullighan CG. Acute lymphoblastic leukemia in children. N Engl J Med. 2015:373(16):1541-52.

4. Jabbour $\mathrm{E}$, Pui $\mathrm{CH}$, Kantarjian $\mathrm{H}$. Progress and innovations in the Management of Adult Acute Lymphoblastic Leukemia. JAMA Oncol. 2018; 4(10):1413-20.

5. Zugmaier G, Goekbuget N, Viardot A, Stelljes M, Neumann S, Horst HA, Reichle A, Marks R, Faul C, Brueggemann M, Holland C, Schmidt M, Mergen N, Goebeler M-E, Einsele H, Bargou RC, Topp MS. Long-term survival in adult patients with relapsed/refractory B-precursor acute lymphoblastic leukemia (ALL) who achieved minimal residual disease (MRD) response following anti-CD19 BiTE ${ }^{\oplus}$ Blinatumomab. Blood. 2014;124(21):2287.

6. Byrd JC, Furman RR, Coutre SE, Flinn IW, Burger JA, Blum KA, Grant B, Sharman JP, Coleman M, Wierda WG, Jones JA, Zhao W, Heerema NA, Johnson AJ, Sukbuntherng J, Chang BY, Clow F, Hedrick E, Buggy JJ, James DF, O'Brien S. Targeting BTK with ibrutinib in relapsed chronic lymphocytic leukemia. N Engl J Med. 2013;369(1):32-42.

7. Byrd JC, Harrington B, O'Brien S, Jones JA, Schuh A, Devereux S, Chaves J, Wierda WG, Awan FT, Brown JR, Hillmen P, Stephens DM, Ghia P, Barrientos JC, Pagel JM, Woyach J, Johnson D, Huang J, Wang X, Kaptein A, Lannutti BJ, Covey T, Fardis M, McGreivy J, Hamdy A, Rothbaum W, Izumi R, Diacovo TG, Johnson AJ, Furman RR. Acalabrutinib (ACP-196) in relapsed chronic lymphocytic leukemia. N Engl J Med. 2016;374(4):323-32.

8. Cortes JE, Apperley JF, DeAngelo DJ, Deininger MW, Kota VK, Rousselot P, Gambacorti-Passerini C. Management of adverse events associated with bosutinib treatment of chronic-phase chronic myeloid leukemia: expert panel review. J Hematol Oncol. 2018;11(1):143.

9. Rossari F, Minutolo F, Orciuolo E. Past, present, and future of Bcr-Abl inhibitors: from chemical development to clinical efficacy. J Hematol Oncol. 2018:11(1):84.

10. Jastaniah W, Elimam N, Abdalla K, AlAzmi AA, Elgaml AM, Alkassar A, Daghistani M, Felimban S. Early vs. late MRD response- and risk-based treatment intensification of childhood acute lymphoblastic leukemia: a prospective pilot study from Saudi Arabia. Exp Hematol Oncol. 2018;7(1):29.

11. Cheng S, Inghirami G, Cheng S, Tam W. Simple deep sequencing-based post-remission MRD surveillance predicts clinical relapse in B-ALL. J Hematol Oncol. 2018;11(1):105

12. Ribrag $\mathrm{V}$, Koscielny S, Bosq J, Leguay $\mathrm{T}$, Casasnovas O, Fornecker L-M, Recher C, Ghesquieres H, Morschhauser F, Girault S, Gouill SL, Ojeda-Uribe M, Mariette C, Cornillon J, Cartron G, Verge V, Chassagne-Clément C, Dombret H, Coiffier B, Lamy T, Tilly H, Salles G. Rituximab and dose-dense chemotherapy for adults with Burkitt's lymphoma: a randomised, controlled, open-label, phase 3 trial. Lancet. 2016;387(10036):2402-11.

13. Thomas DA, Faderl S, O'Brien S, Bueso-Ramos C, Cortes J, Garcia-Manero G, Giles FJ, Verstovsek S, Wierda WG, Pierce SA, Shan J, Brandt M, Hagemeister FB, Keating MJ, Cabanillas F, Kantarjian $\mathrm{H}$. Chemoimmunotherapy with hyper-CVAD plus rituximab for the treatment of adult Burkitt and Burkitt-type lymphoma or acute lymphoblastic leukemia. Cancer. 2006;106(7):1569-80.

14. Thomas DA, O'Brien S, Faderl S, Garcia-Manero G, Ferrajoli A, Wierda W, Ravandi F, Verstovsek S, Jorgensen $J$, Bueso-Ramos C, Andreeff M, Pierce S, Garris R, Keating MJ, Cortes J, Kantarjian HM. Chemoimmunotherapy with a modified hyper-CVAD and rituximab regimen improves outcome in de novo Philadelphia chromosome-negative precursor B-lineage acute lymphoblastic leukemia. J Clin Oncol. 2010;28(24):3880-9.

15. King AC, Pappacena J, Tallman MS, Park JH, Geyer MB. Blinatumomab administered concurrently with Oral tyrosine kinase inhibitor therapy is a well-tolerated consolidation strategy and eradicates measurable residual disease in adults with Philadelphia chromosome positive acute lymphoblastic leukemia. Blood. 2018;132(Suppl 1):1414.

16. Koprivnikar J, Marcotulli D, Jones E, Perry G, Kuo Y-H, Gagnon J, Aviador M, Stanislaus G, McCloskey J. Blinatumumab induces responses in Extramedulary B-cell acute lymphoid leukemia (B-ALL) and lymphoid blast crisis chronic myelogenous leukemia (CML), and rarely results in CD19 negative relapse. Blood. 2018;132(Suppl 1):2703

17. von Stackelberg A, Locatelli F, Zugmaier G, Handgretinger R, Trippett TM, Rizzari C, Zwaan CM, Bhojwani D, Dubois SG, Bader P, Borkhardt A, O'Brien M, Rheingold SR, Cooper TM, Hu K, Mergen N, Fischer A, Zhu M, Hijazi Y, Whitlock J, Gore L. Phase 1/2 study in pediatric patients with relapsed/ refractory B-cell precursor acute lymphoblastic leukemia (BCP-ALL) receiving Blinatumomab treatment. Blood. 2014;124(21):2292.

18. Gokbuget N, Kelsh M, Chia V, Advani A, Bassan R, Dombret H, Doubek M, Fielding AK, Giebel S, Haddad V, Hoelzer D, Holland C, Ifrah N, Katz A, Maniar T, Martinelli G, Morgades M, O'Brien S, Ribera JM, Rowe JM, Stein A, Topp M, Wadleigh M, Kantariian H. Blinatumomab vs historical standard therapy of adult relapsed/refractory acute lymphoblastic leukemia. Blood Cancer J. 2016;6(9):e473.

19. Sanford M. Blinatumomab: first global approval. Drugs. 2015;75(3):321-7.

20. Li Z, Song W, Rubinstein M, Liu D. Recent updates in cancer immunotherapy: a comprehensive review and perspective of the 2018 
China Cancer immunotherapy workshop in Beijing. J Hematol Oncol. 2018; 11(1):142.

21. Thomas X. Blinatumomab: a new era of treatment for adult ALL? Lancet Oncol. 2014;16(1):6-7.

22. Topp MS, Gokbuget N, Stein AS, Zugmaier G, O'Brien S, Bargou RC, Dombret $H$, Fielding AK, Heffner L, Larson RA, Neumann S, Foa R, Litzow M, Ribera JM, Rambaldi A, Schiller G, Bruggemann M, Horst HA, Holland C, Jia C, Maniar T, Huber B, Nagorsen D, Forman SJ, Kantarjian HM. Safety and activity of blinatumomab for adult patients with relapsed or refractory Bprecursor acute lymphoblastic leukaemia: a multicentre, single-arm, phase 2 study. Lancet Oncol. 2014;16(1):57-66.

23. Zhang $X$, Yang $Y$, Fan $D$, Xiong D. The development of bispecific antibodies and their applications in tumor immune escape. Exp Hematol Oncol. 2017; 6(1):12.

24. Diggs LP, Hsueh EC. Utility of PD-L1 immunohistochemistry assays for predicting PD-1/PD-L1 inhibitor response. Biomarker Res. 2017;5(1):12.

25. Zhang C, Liu J, Zhong JF, Zhang X. Engineering CAR-T cells. Biomarker Res, 2017;5(1):22.

26. Liu B, Song Y, Liu D. Clinical trials of CAR-T cells in China. J Hematol Oncol. 2017;10(1):166

27. Wang Z, Wu Z, Liu Y, Han W. New development in CAR-T cell therapy. J Hematol Oncol. 2017;10(1):53.

28. Zhang L-N, Song Y, Liu D. CD19 CAR-T cell therapy for relapsed/refractory acute lymphoblastic leukemia: factors affecting toxicities and long-term efficacies. J Hematol Oncol. 2018;11(1):41.

29. Zhao J, Lin Q, Song Y, Liu D. Universal CARs, universal T cells, and universal CAR T cells. J Hematol Oncol. 2018;11(1):132.

30. June CH, O'Connor RS, Kawalekar OU, Ghassemi S, Milone MC. CAR T cell immunotherapy for human cancer. Science. 2018;359(6382):1361-5.

31. Wang J, Hu Y, Huang H. Current development of chimeric antigen receptor T-cell therapy. Stem Cell Invest. 2018;5:44.

32. Sadelain M, Brentjens R, Riviere I. The basic principles of chimeric antigen receptor design. Cancer Discov. 2013;3(4):388-98.

33. Wei G, Ding L, Wang J, Hu Y, Huang H. Advances of CD19-directed chimeric antigen receptor-modified T cells in refractory/relapsed acute lymphoblastic leukemia. Exp Hematol Oncol. 2017;6(1):10.

34. Liu D, Zhao J. Cytokine release syndrome: grading, modeling, and new therapy. J Hematol Oncol. 2018;11(1):121.

35. Garfall AL, Maus MV, Hwang WT, Lacey SF, Mahnke YD, Melenhorst JJ, Zheng Z, Vogl DT, Cohen AD, Weiss BM, Dengel K, Kerr ND, Bagg A, Levine $\mathrm{BL}$, June $\mathrm{CH}$, Stadtmauer EA. Chimeric antigen receptor T cells against CD19 for multiple myeloma. N Engl J Med. 2015;373(11):1040-7.

36. Grupp SA, Kalos M, Barrett D, Aplenc R, Porter DL, Rheingold SR, Teachey DT, Chew A, Hauck B, Wright JF, Milone MC, Levine BL, June CH. Chimeric antigen receptor-modified T cells for acute lymphoid leukemia. N Engl J Med. 2013;368(16):1509-18.

37. June $\mathrm{CH}$, Sadelain M. Chimeric antigen receptor therapy. N Engl J Med. 2018:379(1):64-73.

38. Maude SL, Frey N, Shaw PA, Aplenc R, Barrett DM, Bunin NJ, Chew A, Gonzalez VE, Zheng Z, Lacey SF, Mahnke YD, Melenhorst JJ, Rheingold SR, Shen A, Teachey DT, Levine BL, June CH, Porter DL, Grupp SA. Chimeric antigen receptor T cells for sustained remissions in leukemia. N Engl I Med. 2014;371(16):1507-17.

39. Maude SL, Laetsch TW, Buechner J, Rives S, Boyer M, Bittencourt H, Bader P, Verneris MR, Stefanski HE, Myers GD, Qayed M, De Moerloose B, Hiramatsu H, Schlis K, Davis KL, Martin PL, Nemecek ER, Yanik GA, Peters C, Baruchel A, Boissel N, Mechinaud F, Balduzzi A, Krueger J, June CH, Levine BL, Wood P, Taran T, Leung M, Mueller KT, et al. Tisagenlecleucel in children and young adults with B-cell lymphoblastic leukemia. N Engl J Med. 2018;378(5):439-48.

40. Porter DL, Levine BL, Kalos M, Bagg A, June CH. Chimeric antigen receptormodified T cells in chronic lymphoid leukemia. N Engl J Med. 2011;365(8): 725-33.

41. Sadelain M, Rivière I, Riddell S. Therapeutic T cell engineering. Nature. 2017; 545:423.

42. Park JH, Rivière I, Gonen $M$, Wang $X$, Sénéchal $B$, Curran $K$, Sauter $C$, Wang Y, Santomasso B, Mead E, Roshal M, Maslak P, Davila M, Brentjens RJ, Sadelain M. Long-Term Follow-up of CD19 CAR Therapy in Acute Lymphoblastic Leukemia. N Engl J Med. 2018;378:449-59.

43. Neelapu SS, Locke FL, Bartlett NL, Lekakis L, Miklos DB, Jacobson CA, Braunschweig I, Oluwole OO, Siddiqi T, Lin Y, Timmerman JM, Stiff PJ, Friedberg JW, Flinn IW, Goy A, Hill BT, Smith MR, Deol A, Farooq U,
McSweeney P, Munoz J, Avivi I, Castro JE, Westin JR, Chavez JC, Ghobadi A, Komanduri KV, Levy R, Jacobsen ED, Witzig TE, et al. Axicabtagene Ciloleuce CAR T-cell therapy in refractory large B-cell lymphoma. N Engl J Med. 2017; 377(26):2531-44.

44. Neelapu SS, Tummala S, Kebriaei P, Wierda W, Locke FL, Lin Y, Jain N, Daver N, Gulbis AM, Adkins S, Rezvani K, Hwu P, Shpall EJ. Toxicity management after chimeric antigen receptor T cell therapy: one size does not fit 'ALL'. Nat Rev Clin Oncol. 2018;15(4):218.

45. Ricart AD. Antibody-drug conjugates of calicheamicin derivative: gemtuzumab ozogamicin and inotuzumab ozogamicin. Clin Cancer Res. 2011;17(20):6417-27.

46. von Minckwitz G, Huang C-S, Mano MS, Loibl S, Mamounas EP, Untch M, Wolmark N, Rastogi P, Schneeweiss A, Redondo A, Fischer HH, Jacot W, Conlin AK, Arce-Salinas C, Wapnir IL, Jackisch C, DiGiovanna MP, Fasching PA, Crown JP, Wülfing P, Shao Z, Rota Caremoli E, Wu H, Lam LH, Tesarowski D, Smitt M, Douthwaite H, Singel SM, Geyer CE. Trastuzumab Emtansine for residual invasive HER2-positive breast Cancer. N Engl J Med. 2018;380(7):617-28.

47. Verma S, Miles D, Gianni L, Krop IE, Welslau M, Baselga J, Pegram M, Oh D-Y, Diéras V, Guardino E, Fang L, Lu MW, Olsen S, Blackwell K. Trastuzumab Emtansine for HER2-positive advanced breast Cancer. N Engl J Med. 2012; 367(19):1783-91.

48. Appelbaum FR, Bernstein ID. Gemtuzumab ozogamicin for acute myeloid leukemia. Blood. 2017;130(22):2373.

49. Muresan B, Mamolo CM, Cappelleri JC, Mokgokong R, Palaka A, Hills RK, Latimer N, Heeg B. Comparison of cure rates between Gemtuzumab Ozogamicin plus standard of care chemotherapy vs standard of care alone in patients with newly diagnosed acute myeloid leukemia. Blood. 2018; 132(Suppl 1):2712.

50. Connors JM, Jurczak W, Straus DJ, Ansell SM, Kim WS, Gallamini A, Younes A, Alekseev S, Illés Á, Picardi M, Lech-Maranda E, Oki Y, Feldman T, Smolewski P, Savage K, Bartlett NL, Walewski J, Chen R, Ramchandren R, Zinzani PL, Cunningham D, Rosta A, Josephson NC, Song E, Sachs J, Liu R, Jolin HA, Huebner D, Radford J. Brentuximab Vedotin with chemotherapy for stage III or IV Hodgkin's lymphoma. N Engl J Med. 2017;378(4):331-44.

51. Longo DL, DeVita VT. Progress in the Treatment of Hodgkin's Lymphoma. N Engl J Med. 2018;378(4):392-4.

52. Lowe EJ, Reilly A, Bollard CM, Barkauskas DA, Buxton AB, Hall D, Saguilig $L$, Sandlund JT. Toxicity Profile of Brentuximab Vedotin in Combination with Chemotherapy for Newly Diagnosed Patients with ALK+ ALCL: A Children\&\#039;s Oncology Group Study ANHL12P1. Blood. 2018; 132(Suppl 1):1625.

53. Kantarjian $H$, Thomas D, Jorgensen J, Jabbour E, Kebriaei P, Rytting M, York S, Ravandi F, Kwari M, Faderl S, Rios MB, Cortes J, Fayad L, Tarnai R, Wang SA, Champlin R, Advani A, O'Brien S. Inotuzumab ozogamicin, an anti-CD22calecheamicin conjugate, for refractory and relapsed acute lymphocytic leukaemia: a phase 2 study. Lancet Oncol. 2012;13(4):403-11.

54. Kantarjian $\mathrm{H}$, Thomas D, Jorgensen J, Kebriaei $\mathrm{P}$, Jabbour E, Rytting M, York S, Ravandi F, Garris R, Kwari M, Faderl S, Cortes J, Champlin R, O'Brien S. Results of inotuzumab ozogamicin, a CD22 monoclonal antibody, in refractory and relapsed acute lymphocytic leukemia. Cancer. 2013;119(15): 2728-36.

55. Jabbour E, Ravandi F, Kebriaei P, Huang X, Short NJ, Thomas D, Sasaki K Rytting M, Jain N, Konopleva M, Garcia-Manero G, Champlin R, Marin D, Kadia T, Cortes J, Estrov Z, Takahashi K, Patel Y, Khouri MR, Jacob J, Garris R, O'Brien S, Kantarjian H. Salvage Chemoimmunotherapy with Inotuzumab Ozogamicin combined with mini-hyper-CVD for patients with relapsed or refractory Philadelphia chromosome-negative acute lymphoblastic leukemia: a phase 2 clinical trial. JAMA Oncol. 2018:4(2):230-4.

56. Jabbour E, Sasaki K, Ravandi F, Huang X, Short NJ, Khouri M, Kebriaei P, Burger J, Khoury J, Jorgensen J, Jain N, Konopleva M, Garcia-Manero G, Kadia T, Cortes J, Jacob J, Montalbano K, Garris R, O'Brien S, Kantarjian HM. Chemoimmunotherapy with inotuzumab ozogamicin combined with minihyper-CVD, with or without blinatumomab, is highly effective in patients with Philadelphia chromosome-negative acute lymphoblastic leukemia in first salvage. Cancer. 2018;124(20):4044-55.

57. Jabbour EJ, DeAngelo DJ, Stelljes M, Stock W, Liedtke M, Gokbuget N, O'Brien S, Wang T, Paccagnella ML, Sleight B, Vandendries E, Advani AS, Kantarjian HM. Efficacy and safety analysis by age cohort of inotuzumab ozogamicin in patients with relapsed or refractory acute lymphoblastic leukemia enrolled in INO-VATE. Cancer. 2018;124(8):1722-32. 
58. Kantarjian $\mathrm{H}$, Jabbour $\mathrm{E}$. Incorporating immunotherapy into the treatment strategies of B-cell adult acute lymphoblastic leukemia: the role of Blinatumomab and Inotuzumab Ozogamicin. Am Soc Clin Oncol Educ Book. 2018:38:574-8.

59. Kantarjian H, Ravandi F, Short NJ, Huang X, Jain N, Sasaki K, Daver N, Pemmaraju N, Khoury JD, Jorgensen J, Alvarado Y, Konopleva M, GarciaManero G, Kadia T, Yilmaz M, Bortakhur G, Burger J, Kornblau S, Wierda W, DiNardo C, Ferrajoli A, Jacob J, Garris R, O'Brien S, Jabbour E. Inotuzumab ozogamicin in combination with low-intensity chemotherapy for older patients with Philadelphia chromosome-negative acute lymphoblastic leukaemia: a single-arm, phase 2 study. Lancet Oncol. 2018;19(2):240-8.

60. Kantarjian HM, Su Y, Jabbour EJ, Bhattacharyya H, Yan E, Cappelleri JC, Marks DI. Patient-reported outcomes from a phase 3 randomized controlled trial of inotuzumab ozogamicin versus standard therapy for relapsed/refractory acute lymphoblastic leukemia. Cancer. 2018:124(10):2151-60.

61. Sasaki K, Kantarjian HM, Ravandi F, Short NJ, Kebriaei P, Huang X, Rytting ME, Jain N, Konopleva MY, Garcia-Manero G, Champlin RE, Kadia TM, Cortes JE, Estrov ZE, Takahashi K, Mace M, Khouri M, Nasnas P, Jacob J, Garris RE, Jabbour EJ. Sequential Combination of Low-Intensity Chemotherapy (Mini-hyper-CVD) Plus Inotuzumab Ozogamicin with or without Blinatumomab in Patients with Relapsed/Refractory Philadelphia Chromosome-Negative Acute Lymphoblastic Leukemia (ALL): A Phase 2 Trial. Blood. 2018;132(Suppl 1):553.

62. Short NJ, Jabbour EJ, Ravandi F, Huang X, Jain N, Sasaki K, Pemmaraju N, Daver NG, Khoury JD, Jorgensen JL, Alvarado Y, Konopleva MY, GarciaManero G, Kadia TM, Yilmaz M, Borthakur G, Burger JA, Kornblau SM, Wierda WG, CD DN, Ferrajoli A, Nasnas P, Jacob J, Garris RE, Brien SM, Kantarjian HM. Chemoimmunotherapy with Inotuzumab Ozogamicin Combined with Mini-Hyper-CVD, with or without Blinatumomab, for Newly Diagnosed Older Patients with Philadelphia Chromosome-Negative Acute Lymphoblastic Leukemia: Results from a Phase II Study. Blood. 2018;132(Suppl 1):36.

63. Kantarjian HM, DeAngelo DJ, Stelljes M, Martinelli G, Liedtke M, Stock W, Gokbuget N, O'Brien S, Wang K, Wang T, Paccagnella ML, Sleight B, Vandendries E, Advani AS. Inotuzumab Ozogamicin versus standard therapy for acute lymphoblastic leukemia. N Engl J Med. 2016:375(8):740-53.

64. Ereño-Orbea J, Sicard T, Cui H, Mazhab-Jafari MT, Benlekbir S, Guarné A, Rubinstein $\mathrm{J}$, Julien J-P. Molecular basis of human CD22 function and therapeutic targeting. Nat Commun. 2017;8(1):764.

65. Stamenkovic I, Seed B. The B-cell antigen CD22 mediates monocyte and erythrocyte adhesion. Nature. 1990;345(6270):74-7.

66. Wilson $\mathrm{GL}$, Fox $\mathrm{CH}$, Fauci AS, Kehrl JH. cDNA cloning of the $B$ cell membrane protein CD22: a mediator of B-B cell interactions. J Exp Med. 1991;173(1):137-46.

67. Walker JA, Smith KGC. CD22: an inhibitory enigma. Immunology. 2008; 123(3):314-25

68. Poe JC, Tedder TF. CD22 and Siglec-G in B cell function and tolerance. Trends Immunol. 2012;33(8):413-20.

69. Silver K, Cornall RJ. Isotype control of B cell signaling. Sci STKE. 2003; 2003(184):pe21.

70. Raponi S, De Propris MS, Intoppa S, Milani ML, Vitale A, Elia L, Perbellini O, Pizzolo G, Foa R, Guarini A. Flow cytometric study of potential target antigens (CD19, CD20, CD22, CD33) for antibody-based immunotherapy in acute lymphoblastic leukemia: analysis of 552 cases. Leuk Lymphoma. 2011; 52(6):1098-107.

71. Lau H, Nagy A, Atwater SK, Cascio MJ, Ohgami RS. An integrated flow cytometry analysis of 286 mature B cell neoplasms identifies CD13 as a useful marker for diagnostic subtyping. Int J Lab Hematol. 2018;40(6): 715-20.

72. DiJoseph JF, Popplewell A, Tickle S, Ladyman H, Lawson A, Kunz A, Khandke K, Armellino DC, Boghaert ER, Hamann P, Zinkewich-Peotti K, Stephens S, Weir N, Damle NK. Antibody-targeted chemotherapy of Bcell lymphoma using calicheamicin conjugated to murine or humanized antibody against CD22. Cancer Immunol Immunother. 2005;54(1):11-24.

73. DiJoseph JF, Armellino DC, Boghaert ER, Khandke K, Dougher MM, Sridharan L, Kunz A, Hamann PR, Gorovits B, Udata C, Moran JK, Popplewell AG, Stephens S, Frost P, Damle NK. Antibody-targeted chemotherapy with CMC-544: a CD22-targeted immunoconjugate of calicheamicin for the treatment of B-lymphoid malignancies. Blood. 2004;103(5):1807-14

74. O'Reilly MK, Tian H, Paulson JC. CD22 is a recycling receptor that can shuttle cargo between the cell surface and endosomal compartments of B cells. J Immunol. 2011;186(3):1554-63.
75. DiJoseph JF, Dougher MM, Evans DY, Zhou BB, Damle NK. Preclinical anti-tumor activity of antibody-targeted chemotherapy with CMC-544 (inotuzumab ozogamicin), a CD22-specific immunoconjugate of calicheamicin, compared with non-targeted combination chemotherapy with CVP or CHOP. Cancer Chemother Pharmacol. 2011;67(4):741-9.

76. DiJoseph JF, Dougher MM, Armellino DC, Evans DY, Damle NK. Therapeutic potential of CD22-specific antibody-targeted chemotherapy using inotuzumab ozogamicin (CMC-544) for the treatment of acute lymphoblastic leukemia. Leukemia. 2007;21:2240.

77. de Vries JF, Zwaan CM, De Bie M, Voerman JSA, den Boer ML, van Dongen JJM, van der Velden VHJ. The novel calicheamicin-conjugated CD22 antibody inotuzumab ozogamicin (CMC-544) effectively kills primary pediatric acute lymphoblastic leukemia cells. Leukemia. 2011;26: 255.

78. DeAngelo DJ, Stock W, Stein AS, Shustov A, Liedtke M, Schiffer CA, Vandendries E, Liau K, Ananthakrishnan R, Boni J, Laird AD, Fostvedt L, Kantarjian HM, Advani AS. Inotuzumab ozogamicin in adults with relapsed or refractory CD22-positive acute lymphoblastic leukemia: a phase 1/2 study. Blood. 2017;1(15):1167-80.

79. George B, Kantarjian H, Jabbour E, Jain N. Role of inotuzumab ozogamicin in the treatment of relapsed/refractory acute lymphoblastic leukemia. Immunotherapy. 2016;8(2):135-43.

80. Kantariian HM, DeAngelo DJ, Advani AS, Stelljes M, Kebriaei P, Cassaday RD, Merchant AA, Fujishima N, Uchida T, Calbacho M, Ejduk AA, O'Brien SM, Jabbour EJ, Zhang H, Sleight BJ, Vandendries ER, Marks DI. Hepatic adverse event profile of inotuzumab ozogamicin in adult patients with relapsed or refractory acute lymphoblastic leukaemia: results from the open-label, randomised, phase 3 INO-VATE study. Lancet Haematol. 2017;4(8):e387-98.

81. Liu D, Zhao J, Song Y, Luo X, Yang T. Clinical trial update on bispecific antibodies, antibody-drug conjugates, and antibody-containing regimens for acute lymphoblastic leukemia. J Hematol Oncol. 2019;12(1):15.

82. DiJoseph JF, Dougher MM, Kalyandrug LB, Armellino DC, Boghaert ER, Hamann PR, Moran JK, Damle NK. Antitumor Efficacy of a Combination of CMC-544 (Inotuzumab Ozogamicin), a CD22-Targeted Cytotoxic Immunoconjugate of Calicheamicin, and Rituximab against NonHodgkin\&\#039;s B-Cell Lymphoma. Clin Cancer Res. 2006;12(1):242.

83. Advani A, Coiffier B, Czuczman MS, Dreyling M, Foran J, Gine E, Gisselbrecht C, Ketterer N, Nasta S, Rohatiner A, Schmidt-Wolf IG, Schuler M, Sierra J, Smith MR, Verhoef G, Winter JN, Boni J, Vandendries E, Shapiro M, Fayad L. Safety, pharmacokinetics, and preliminary clinical activity of inotuzumab ozogamicin, a novel immunoconjugate for the treatment of B-cell nonHodgkin's lymphoma: results of a phase I study. J Clin Oncol. 2010;28(12): 2085-93.

84. Ogura M, Tobinai $K$, Hatake $K$, Uchida T, Kasai M, Oyama T, Suzuki T, Kobayashi Y, Watanabe T, Azuma T, Mori M, Terui Y, Yokoyama M, Mishima Y, Takahashi S, Ono C, Ohata J. Phase I study of inotuzumab ozogamicin (CMC-544) in Japanese patients with follicular lymphoma pretreated with rituximab-based therapy. Cancer Sci. 2010;101(8):1840-5.

85. Fayad L, Offner F, Smith MR, Verhoef $G$, Johnson P, Kaufman JL, Rohatiner A Advani A, Foran J, Hess G, Coiffier B, Czuczman M, Gine E, Durrant S, Kneissl M, Luu KT, Hua SY, Boni J, Vandendries E, Dang NH. Safety and clinical activity of a combination therapy comprising two antibody-based targeting agents for the treatment of non-Hodgkin lymphoma: results of a phase I/II study evaluating the immunoconjugate inotuzumab ozogamicin with rituximab. J Clin Oncol. 2013;31(5):573-83.

86. Ogura M, Hatake K, Ando K, Tobinai K, Tokushige K, Ono C, Ishibashi T, Vandendries E. Phase I study of anti-CD22 immunoconjugate inotuzumab ozogamicin plus rituximab in relapsed/refractory B-cell non-Hodgkin lymphoma. Cancer Sci. 2012;103(5):933-8.

87. Ogura M, Tobinai K, Hatake K, Davies A, Crump M, Ananthakrishnan R, Ishibashi T, Paccagnella ML, Boni J, Vandendries E, MacDonald D. Phase I study of Inotuzumab Ozogamicin combined with R-CVP for relapsed/ refractory CD22+ B-cell non-Hodgkin lymphoma. Clin Cancer Res. 2016; 22(19):4807-16.

88. Sangha R, Davies A, Dang NH, Ogura M, MacDonald DA, Ananthakrishnan R, Paccagnella ML, Vandendries E, Boni J, Goh YT. Phase 1 study of inotuzumab ozogamicin combined with R-GDP for the treatment of patients with relapsed/refractory CD22+ B-cell non-Hodgkin lymphoma. J Drug Assess. 2017;6(1):10-7.

89. Kebriaei P, Wilhelm K, Ravandi F, Brandt M, de Lima M, Ciurea S, Worth L, O'Brien S, Thomas D, Champlin RE, Kantarjian H. Feasibility of Allografting in 
patients with advanced acute lymphoblastic leukemia after salvage therapy with Inotuzumab Ozogamicin. Clin Lymphoma, Myeloma Leuk. 2013;13(3): 296-301.

90. Dalle J-H, Giralt SA. Hepatic Veno-occlusive disease after hematopoietic stem cell transplantation: risk factors and stratification, prophylaxis, and treatment. Biol Blood Marrow Transplant. 2016;22(3):400-9.

Ready to submit your research? Choose BMC and benefit from:

- fast, convenient online submission

- thorough peer review by experienced researchers in your field

- rapid publication on acceptance

- support for research data, including large and complex data types

- gold Open Access which fosters wider collaboration and increased citations

- maximum visibility for your research: over $100 \mathrm{M}$ website views per year

At $\mathrm{BMC}$, research is always in progress.

Learn more biomedcentral.com/submissions 